\title{
O HomeM Que NÃo EstaVA LÁ E A VolTa Dos Que NÃO FORAM: TRADUÇÃO E AUTORIA A PARTIR DE BARTHES, FOUCAULT E AGAMBEN
}

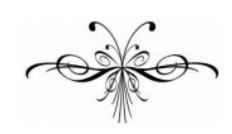

JoÃo Paulo Matedi Alves

Resumo: partindo dos textos "A morte do autor" (Roland Barthes), "O que é um autor?" (Michel Foucault) e "O autor como gesto" (Giorgio Agamben), pretende-se demonstrar que, apesar de a impessoalização da escrita e a relativização/o alargamento da autoria serem temas desses trabalhos, o tradutor não foi levado em conta nesse campo de forças. Embora esses autores tenham alargado o campo da escrita, ao colocarem em cena atores antes desprestigiados - a escrita em si mesma e o leitor -, o tradutor continuou ignorado - permaneceu tabu. Tais constatações provocam a revolta de alguns, mas a verdade é que esses autores trabalharam no campo do possível - do que estava posto como possível em seus contextos; afinal, se a literatura reivindicou sua autonomia ao menos desde o romantismo, a tradução ainda não conquistou esse status, pois foi durante muito tempo (e para muitos ainda é) considerada subliteratura (século XVI), subcrítica (século XIX) e uma linguística ou poética aplicadas (século XX). Seguindo esses trabalhos e também Leonor Arfuch e Lawrence Venuti, outros pontos serão colocados: (1) o autor, como queria Barthes, não morreu; (2) a afirmação de desaparição do autor e a tentativa de matá-lo não eram legítimas, em certa medida; (3) a não morte do autor foi também um dos fatores que impediram a entrada em cena do tradutor. Assim, buscar-se-á problematizar pressupostos basilares de Barthes, Foucault e Agamben, para recuperar à autoria elementos que lhe foram arrebatados e vislumbrar o quadro a que pertencem tradutor e tradução.

Palavras-chave: Tradução; tradutor; autoria.

\begin{abstract}
Death of the Author" (Roland Barthes), "What is an author?" (Michel Foucault), and "The Author as Gesture" (Giorgio Agamben), this study aims at showing that even though the impersonalization of writing and the relativization/broadening of authorship are the themes in these studies, the translator was not taken into account. Although these authors have broadened the field of writing, when they put on stage actors who had been discredited - writing itself and the reader - the translator remained ignored, a taboo. This fact may anger some, but the truth is that these authors worked within their possibilities, within what was attainable in their settings. After all, if literature has claimed its autonomy at least since Romanticism, translation has not yet achieved this status. For a long time, it was - or has been, for many - considered subliterature (16th century), subcriticism (19th century), and applied linguistics or poetry (20th century). Following these studies, as well as Leonor Arfuch and Lawrence Venuti's, other points will also be highlighted, such as (1) the author, as Barthes wanted, is not dead; (2) the affirmation of the author's disappearance and the attempt of killing him were not authentic, to a certain extent; (3) the author's nondeath was also one of the factors that prevented the translator from coming onto stage. Therefore, this study aims at questioning Barthes, Foucault and Agamben's fundamental premises in order to recover elements that have been taken from authorship and glimpse at the picture to which the translator and translation belong.
\end{abstract}

Keywords: Translation; translator; authorship.

Scientia Traductionis, n.13, 2013 
se

nasce

morre nasce

morre nasce morre

re

desnasce

desmorre desnasce

desmorre desnasce desmorre

nascemorrenasce

morrenasce

morre

se

Haroldo de Campos renasce remorre renasce remorre renasce remorre re 
(BARTHES, 1987, p. 49, grifo do autor), fruto do pensamento humano ocidental, que desemboca no "prestígio pessoal do indivíduo" (BARTHES, 1987, p. 49). Por isso o autor reina e, assim, biografismos esdrúxulos ocorrem.

Mais à frente, ainda na tentativa de destronar a ideia de que o autor é o proprietário da linguagem, Barthes contrapõe ao autor a figura do scriptor. Este nasce "ao mesmo tempo que o seu texto" (BARTHES, 1987, p. 51), não precede nem excede a sua escrita, não apresenta um tempo para além da enunciação (BARTHES, 1987, p. 51) e constrói um texto de puro signo. Já o autor é um ser histórico, e a escrita não pertence à história - é o hic et nunc. Faz-se ainda uma crítica à Crítica, uma vez que esta, por conveniência, ancora-se no autor em vez de no leitor. Dar um autor a um texto é fechá-lo, dotá-lo de um significado último, porém a "escrita faz incessantemente sentido, mas é sempre para o evaporar" (BARTHES, 1987, p. 52). O leitor, por sua vez, segundo Barthes, é o lugar em que se reúnem os "vapores" de um texto, suas escritas: "a unidade de um texto não está na sua origem, mas no seu destino” (BARTHES, 1987, p. 53). Em suma: "para devolver à escrita o seu devir, é preciso inverter o seu mito: o nascimento do leitor tem de pagar-se com a morte do autor" (BARTHES, 1987, p. 53).

Um ano depois, em 1969, vem à luz “O que é um autor?”, de Foucault. Como o próprio título denuncia, aqui o pensador francês não pretende "lavar a honra em sangue" - o serviço já foi feito, "tudo isso é conhecido", afinal "faz bastante tempo que a crítica e a filosofia constataram esse desaparecimento ou morte do autor" (FOUCAULT, 2001, p. 269). Como ele chegou depois, irá apenas "velar o cadáver”, pois, "na escrita, não se trata da manifestação ou da exaltação do gesto de escrever; não se trata da amarração de um sujeito em uma linguagem; trata-se da abertura de um espaço onde o sujeito que escreve não para de desaparecer” (FOUCAULT, 2001, p. 268). E esse raciocínio é completado quando, ecoando Barthes, em certa medida, trata da relação entre escrita e morte:

essa relação [...] se manifesta no desaparecimento das características individuais do sujeito que escreve; através de todas as chicanas que ele estabelece entre ele e o que ele escreve, o sujeito que escreve despista todos os signos de sua individualidade particular; a marca do escritor não é mais que a singularidade de sua ausência; é preciso que ele faça o papel do morto no jogo da escrita (FOUCAULT, 2001, p. 269).

O objetivo de Foucault é “examinar unicamente a relação do texto com o autor, a maneira com que o texto aponta para essa figura que lhe é exterior e anterior, pelo menos aparentemente" (FOUCAULT, 2001, p. 267, grifo meu). Nesse sentido, Foucault analisa, valendo-se de exemplos, o nome do autor em confronto com demais nomes próprios e chega à conclusão de que o nome do autor apresenta funcionamento particular e autônomo. Nem no campo da descrição nem no da designação pode-se partir dos mesmos pressupostos que seriam válidos para outros nomes próprios - "a ligação do nome próprio com o indivíduo nomeado e a ligação do nome do autor com o que ele nomeia não são isomorfas nem funcionam da mesma maneira” (FOUCAULT, 2001, p. 272). Para o autor francês, "um nome de autor não é simplesmente um elemento em um discurso [...]; ele exerce um certo papel em relação ao discurso: assegura uma função classificatória; tal nome permite reagrupar um certo número de textos, delimitá-los, deles excluir alguns, opô-los a outros” (FOUCAULT, 2001, p. 273). E continua: “o nome do autor funciona para caracterizar um certo modo de ser do discurso" (FOUCAULT, 2001, p. 273). Em consequência, um nome de autor à testa de um discurso dá a esse dis- 
curso certo status, é uma palavra que deve ser recebida de modo especial, não é palavra cotidiana:

ele [um nome de autor] manifesta a ocorrência de um certo conjunto de discurso, e refere-se ao status desse discurso no interior de uma sociedade e de uma cultura. O nome do autor não está localizado no estado civil dos homens, não está localizado na ficção da obra, mas na ruptura que instaura um certo grupo de discursos e seu modo singular de ser. Consequentemente, poder-se-ia dizer que há, em uma civilização como a nossa, um certo número de discursos que são providos da função "autor", enquanto outros são dela desprovidos. Uma carta particular pode ter um signatário, ela não tem autor; um contrato pode ter um fiador, ele não tem autor. Um texto anônimo que se lê na rua em uma parede terá um redator, não terá um autor. A função autor é, portanto, característica do modo de existência, de circulação e de funcionamento de certos discursos no interior de uma sociedade (FOUCAULT, 2001, p. 274).

Aproximadamente trinta anos depois, Agamben retoma a questão da autoria em “O autor como gesto" (que nada mais é que a releitura da noção de autor a partir de "O que é um autor?”) e, parafraseando resumidamente Foucault, explicita “as diferentes características da função-autor no nosso tempo":

[1] um regime particular de apropriação, que sancionou o direito de autor e, ao mesmo tempo, a possibilidade de distinguir e selecionar os discursos entre textos literários e textos científicos, aos quais correspondem modos diferentes da própria função; [2] a possibilidade de autenticar os textos, constituindo-os em cânone ou, pelo contrário, a possibilidade de certificar o seu caráter apócrifo; [3] a dispersão da função enunciativa simultaneamente em mais sujeitos que ocupam lugares diferentes; [4] e, por fim, a possibilidade de construir uma função transdiscursiva, que constitui o autor, para além dos limites da sua obra, como "instaurador de discursividade" (Marx é muito mais que o autor de O capital, e Freud é bem mais que o autor de Interpretação dos sonhos) (AGAMBEN, 2007, p. 56). ${ }^{1}$

Em “O autor como gesto” há duas passagens que nos interessam mais de perto. A primeira surge logo na primeira página, quando, ocupando-se do trabalho de Foucault, o autor italiano lembra que, "logo depois das primeiras frases, Foucault formula, com uma citação de Beckett (' $O$ que importa quem fala, alguém disse, o que importa quem fala'), a indiferença a respeito do autor como mote ou princípio fundamental da ética da escritura contemporânea” (AGAMBEN, 2007, p. 55). Com essa fórmula, Foucault "fundamenta a distinção entre duas noções que frequentemente são confundidas: o autor como indivíduo real, que ficará [...] fora de campo, e a função-autor, a única na

\footnotetext{
${ }^{1}$ Não me parece que a caracterização dada por Agamben seja tão rigorosa a ponto de seguir o texto de Foucault fielmente, pois o autor francês enumera quatro características para a função-autor, tomando como mote tão só o autor de um livro ou texto. Agamben, por seu turno, inclui em sua sequência os "instauradores de discursividade”, que é uma fórmula presente em Foucault, mas este autor não a inclui entre as quatro características aludidas anteriormente. Em consequência, já que o autor italiano soma mais uma os "instauradores de discursividade" - às características listadas no trabalho de 1969, por que ele descreve quatro e não cinco propriedades (as quatro dadas por Foucault e aquela trazida a reboque por ele)? Em relação a isso, nada mais podemos fazer que conjeturar, e são duas pelo menos as possibilidades: ou Agamben excluiu um elemento da lista sem se dar conta, hipótese improvável, ou, o que é bem possível, conjugou duas das propriedades de Foucault em uma das suas - mais claramente, a segunda característica apresentada por Agamben englobaria a segunda e a terceira apontadas por Foucault.
} 
qual Foucault concentrará toda a sua análise” (AGAMBEN, 2007, p. 55-56). O irônico é que Agamben identifica na sentença de Beckett um dado curioso:

há [...] alguém que, mesmo continuando anônimo e sem rosto, proferiu o enunciado, alguém sem o qual a tese, que nega a importância de quem fala, não teria podido ser formulada. $\mathrm{O}$ mesmo gesto que nega qualquer relevância à identidade do autor afirma, no entanto, a sua irredutível necessidade (AGAMBEN, 2007, p. 55).

A segunda passagem vem exposta algumas páginas à frente, num trecho em que a poesia é evocada; aí, o autor define o que é gesto: "o lugar - ou melhor, o ter lugar - do poema não está, pois, nem no texto nem no autor (ou no leitor): está no gesto no qual autor e leitor se põem em jogo no texto e, ao mesmo tempo, infinitamente fogem disso" (AGAMBEN, 2007, p. 62-63).

Todo esse longo trecho acerca desses trabalhos tem como objetivo, além de situar o leitor sobre a matéria constante neles e deixar entrever certo fio que os une (a impessoalização da escrita e a relativização/o alargamento da autoria), mostrar como os argumentos partem de uma visada mais incisiva (Barthes) para considerações um tanto amenas (Foucault) até chegar a argumentos mais englobantes (Agamben).

Todavia, ainda que todos tenham, de alguma forma, alargado de modo salutar o campo de forças da escrita, ou seja, foram trazidos à cena atores antes desprestigiados a escrita em si mesma e o leitor -, em lugar algum - e isso também nos move mais diretamente aqui - a figura do tradutor foi considerada. Os textos findaram e o vocábulo “tradutor” permanece tabu. Sem dúvida, entretanto, podemos subentendê-lo aqui e ali, quando, por exemplo, Barthes, na tentativa de devolver à escrita seu devir, destaca, como já antecipado no segundo parágrafo, que "um texto não é feito de uma linha de palavras, libertando um sentido único [...], mas um espaço de dimensões múltiplas, onde se casam e se contestam escritas variadas, nenhuma das quais é original” (1987, p. 51-52) ou quando Foucault releva o caráter discursivo do autor e a escrita como jogo, o que o obriga a forjar a fórmula função-autor, ou ainda, e enfim, quando Agamben articula texto, leitor e autor num jogo infindo. Vale lembrar que Paul Valéry, a certa altura de suas "Variações sobre as Bucólicas de Virgílio", se antecipara a essas colocações, ao reunir as escritas em um mesmo e único ponto de interseção - "escrever o que quer que seja [...] é um trabalho de tradução perfeitamente comparável ao que opera a transmutação de um texto de uma língua a outra” (VALÉRY, 2004, p. 197). Não há escritas, há escrita; em outras palavras, há tradutor, há escritor, etc., mas todos, apesar das singularidades que os separam, participam de um único roteiro, o da escrita (no singular). São atores desse/nesse cenário.

Porém, embora seja possível deduzir, no quadro dessas fórmulas de pensamento, a participação do tradutor no complexo da escrita, a verdade é uma só: o tradutor permanece à sombra e a sua atividade, a tradução, engessou-se como atividade ancilar $\mathrm{e}$ suspeita (BERMAN, 2002, p. 15). Além disso, ainda que pudéssemos ${ }^{2}$, exagerando, é óbvio, ver nos trabalhos de Barthes, Foucault e Agamben uma dicotomia entre "produtores" e "receptores" da escrita, de modo que o tradutor figuraria entre os primeiros, isso sem dúvida não seria suficiente, pois os estatutos do autor e do tradutor na produção textual são singulares: generalizando, aquele parte de um primeiro impulso, enquanto este junta ao seu impulso aquele primeiro - a tradução mantém com o original uma re-

\footnotetext{
${ }^{2}$ Levantei uma conjetura absurda, que não figura nos textos de Barthes, Foucault e Agamben, por isso uso o pretérito imperfeito do subjuntivo.
} 
lação "filial". Autor e tradutor não podem ocupar o mesmo espaço. Walter Benjamin, em “A tarefa-renúncia do tradutor” (2001), foi taxativo quanto ao lugar particular ocupado pelo texto original e pela tradução.

Mas, em suma, qual seria a questão a nos desafiar no presente trabalho? Estaríamos simplesmente magoados pela obliteração de uma classe? Ou quem sabe estejamos no divã psicanalítico lamentando a castração? Ou ainda, talvez, a miragem babélica nos tenha petrificado qual medusa? Não, nada disso. O objetivo é tentar entender, ainda que em linhas gerais, por que a morte do autor não se pagou também com o nascimento do tradutor. Se outros agentes da escrita foram abraçados, por que o tradutor nem aqui teve lugar? Por que, ainda, alguém teve de morrer? Por que uma voz teve de ser posta no silêncio para que outra emergisse do Hades? Não se deve fazer comércio com almas. Esgotemos antes o campo do possível (Píndaro) - "porque os corpos se entendem, mas as almas não" (BANDEIRA, 1993, p. 206).

O surpreendente, contudo, é que todos esses autores estão no campo do possível. Declararam ou reconheceram a morte do autor e não deram a mínima para o tradutor justamente porque suas épocas assim pensavam ou reclamavam por isso. Barthes justifica a morte do autor basicamente por duas vias (complementares): (1) segundo ele, o autor não fez nada mais que limitar o campo de extensão e interpretação das obras; o psicologismo do autor, o recurso à sua interioridade (e também à sua história) tirou da linguagem a sua performance, sua recusa de um sentido único - "dar um Autor a um texto é impor a esse texto um mecanismo de segurança, é dotá-lo de um significado último, é fechar a escrita” (BARTHES, 1987, p. 52). (2) Para Barthes, "para devolver à escrita o seu devir, é preciso inverter o seu mito: o nascimento do leitor tem de pagar-se com a morte do autor” (BARTHES, 1987, p. 53). O nascimento do leitor significa dar à escrita unidade: "o leitor é o espaço exacto em que se inscrevem, sem que nenhuma se perca, todas as citações de que uma escrita é feita; a unidade de um texto não está na sua origem, mas no seu destino” (BARTHES, 1987, p. 53).

Foucault, embora possua motivações diversas das de Barthes, tinha no horizonte algumas preocupações similares às deste último e por meio delas (e de muitas outras) justifica a morte ou desaparecimento do autor:

o autor não é uma fonte infinita de significações que viriam preencher a obra, o autor não precede as obras. Ele é um certo princípio funcional pelo qual, em nossa cultura, delimita-se, exclui-se ou seleciona-se: em suma, o princípio pelo qual se entrava a livre circulação, a livre manipulação, a livre composição, decomposição, recomposição da ficção (FOUCAULT, 2001, p. 288).

Agamben não necessita de qualquer justificativa seja lá para o que for, mas, ainda assim, repete os dois mestres: "o autor estabelece [...] o limite para além do qual nenhuma interpretação pode ir” (AGAMBEN, 2007, p. 63). No entanto, sua época exige que se levem em conta os últimos trinta anos de forma explícita, daí a afirmação: "tão ilegítima quanto a tentativa de construir a personalidade do autor através da obra é a de tornar seu gesto a chave secreta da leitura” (AGAMBEN, 2007, p. 63). Em outras palavras e tendo em vista também a definição de gesto tal qual citada acima, no nono parágrafo, o autor italiano viu-se obrigado, instigado e com as armas necessárias a se libertar da miragem da recepção (do leitor) barthesiana e do "abstracionismo"³ foucaultiano.

\footnotetext{
${ }^{3}$ Uso essa palavra porque, ao ler o ensaio de Foucault, é possível sentir a falta de algo, como se o texto ainda estivesse inacabado; aliás, melhor, como se o texto fosse uma proposta a ser desenvolvida. Talvez passagens como a que segue, de Foucault, confirmem tal sensação: "lamento muito não ter podido trazer,
} 
Sua ideia de gesto não cria privilégios, nem parte do pressuposto de que o leitor e a escrita só terão espaço se o autor se retirar por completo; ele os coloca numa mesma situação de jogo, em que a subjetividade do autor salta aos olhos ao mesmo tempo que incessantemente evapora e dá lugar àquela do leitor, pois na escrita nada se fixa em definitivo - é como o vidro, que pode exibir as marcas de um rosto que foi pressionado contra ele, mas que um simples passar de pano apaga e deixa espaço a outro rosto e a mais outro e assim por diante. Entretanto, para o leitor ou autor ingênuos, que sequer veem a marca do rosto por considerá-la óbvia, o vidro é um obstáculo intransponível, pois sua transparência torna-se seu maior obstáculo, onde vão dar com a cara... e depois vem o pano.

Reparemos, no entanto, que mesmo Agamben, munido dos citados trinta anos, não traz à tona o tradutor. Mesmo após um texto capital como "A tarefa-renúncia do tradutor”, de Walter Benjamin, mesmo após uma publicação fundamental e emblemática como Depois de Babel: questões de linguagem e tradução, de George Steiner, mesmo após a tentativa, cada vez mais real, da constituição de um raciocínio tradutológico autônomo; em suma, mesmo após todo o desenvolvimento da chamada Teoria da Tradução, e mesmo após a tímida, porém real, incursão dos estudos de tradução pelo mundo acadêmico ${ }^{4}$, ainda assim a autoria permanece sendo propriedade de um único e só dono. E mesmo que Agamben incluísse o tradutor no hall de seu gesto, isso não seria entendido e valorizado, senão como gesto obsceno. Isso é irônico, pois, ao constatarmos que o tradutor não chegou, temos a atenção voltada para o fato de que o autor nunca se foi...

Mas, como eu ia dizendo, o surpreendente é que todos esses autores estão no campo do possível. Jacques Rancière, na parte final de seu livro Políticas da escrita, em um trecho intitulado "Os enunciados do fim e do nada", discute, entre outras coisas, o chamado Revisionismo, "teoria” que nega a ocorrência do genocídio judeu durante a Segunda Guerra. A negação revisionista, grosso modo, nasce do fato de não ser possível, segundo os revisionistas, provar materialmente o massacre, seja pela inexistência de provas materiais, seja pela inexistência, à época, de recursos materiais que permitissem extermínios em tão grande escala, seja, enfim, pelo não casamento entre realismo e possibilidade: não importa se ele ocorreu, importa saber que ele não era possível, e não sendo possível ele não pertence a um quadro realista e, assim, não ocorreu - "o realismo não é o partido do real, é o partido do possível” (RANCIÈRE, 1995, p. 237). Daí se deduz a íntima aderência entre essa possibilidade e esse realismo ao tempo - uma vez que em determinada época não é possível, racionalmente, manter coesa toda uma série de causas e efeitos, isso indica que não estamos na esfera do realismo. E conquanto mais tarde pululem por toda parte provas em contrário, não importa, uma vez que provas estão a serviço tão só da demonstração, mas, como diria Nietzsche, "o que tem necessidade de ser demonstrado não vale a pena de ser acreditado” (apud RANCIÈRE, 1995, p. 239) - "o acontecimento do extermínio é uma configuração insustentável entre o pensamento, o possível e o real” (RANCIÈRE, 1995, p. 241).

para o debate que agora vai se seguir, nenhuma proposição positiva: no máximo, direções para um trabalho possível, caminhos de análise” (FOUCAULT, 2001, p. 286).

4 “Não obstante a prática da tradução ser uma actividade milenária, o estudo especializado da tradução no mundo ocidental é um fenómeno recente do século XX. Por outra parte, quanto ao seu estatuto académico, só a partir dos anos oitenta é que se pode falar nos Estudos de Tradução como disciplina independente” (PINILLA; SÁNCHEZ, 1998, p. 7). 
Podemos tomar Rancière como guia para a afirmação que fiz acima de que Barthes, Foucault e Agamben estão no campo do possível em suas tentativas de matar o autor ou "democratizar a autoria". No que diz respeito ao campo intelectual, suas tentativas são legítimas, o quadro não era de todo desfavorável, era possível o alinhamento entre o pensamento, o possível e o real. Tanto é assim que Barthes destaca o papel de Mallarmé, de Valéry, de Proust, do Surrealismo e da linguística no apagamento do autor. E Foucault, tratando a escrita como um jogo de signos, em que suas próprias regras são transgredidas, de modo que ela extravasa, acusa "que a escrita de hoje se libertou do tema da expressão: ela se basta a si mesma” (FOUCAULT, 2001, p. 268) - sem contar o Formalismo, o Estruturalismo, e outras manifestações de vanguarda. Em outras palavras, o autor morreu, ou, melhor, assim o quiseram, porque era tempo de morrer. A situação tornou-se insustentável justamente porque os elementos materiais estavam todos postos. A escrita assumira estatuto diverso daquele de séculos atrás, e até mesmo a filologia, “reduto do autor”, perdera sua força e estava em xeque. Mas algo ou alguém tinha que ser colocado no lugar do autor. A solução de Barthes foi, a partir do estatuto que a escrita já havia conquistado, ocupar-se do leitor. Foucault preferiu cunhar uma fórmula (função-autor) para designar uma existência inexistente, que é agente na medida mesma em que é paciente - a escrita passou a ser lugar de um belo paradoxo. Em outras palavras, o autor escreve (agente) para ser escrito (paciente) - a escrita governa -, afinal, “o sujeito que escreve despista todos os signos de sua individualidade particular; a marca do escritor não é mais que a singularidade de sua ausência; é preciso que ele faça o papel do morto no jogo da escrita” (FOUCAULT, 2001, p. 269).

Para o tradutor, por sua vez, valeu o pensamento revisionista - os elementos materiais não estavam postos. Não era hora de nascer, e, caso dessem-lhe a luz, seria natimorto. A configuração era (como para muitos ainda é) insustentável entre o pensamento, o possível e o real. Para se ter uma ideia, mesmo nos centros ditos desenvolvidos a tradução tinha de ser legitimada, devia provar que era possível existir, embora seja prática milenar das mais notáveis. Georges Mounin, por exemplo, em 1963 ainda se via obrigado a publicar um livro como Os problemas teóricos da tradução para provar que a tradução não só é possível como também viável. A certa altura, ao justificar, no âmbito dos estudos linguísticos, a existência de seu livro e da pesquisa ali contida, afirma que "seria quase possível dizer que a existência da tradução constitui o escândalo da linguística contemporânea. Até hoje, o exame desse escândalo tem sido mais ou menos recusado" (MOUNIN, 1975, p. 19). Em 1975, estamos ainda (ou já?) no tempo de nascimento “da primeira obra de maior fôlego dedicada a uma reflexão abrangente sobre questões teóricas da tradução e que procura estabelecer um espaço próprio para ela no interior da tradição" (LAGES, 2007, p. 29, grifo da autora); trata-se de Depois de Babel: questões de linguagem e tradução, de George Steiner. No quadro nacional, só em 1952 foi publicado o livro Escola de tradutores, primeira obra dedicada exclusivamente à tradução e curiosamente escrita por um estrangeiro, Paulo Rónai, um húngaro muito brasileiro. Dois anos depois veio a lume a segunda, A arte de traduzir, de Brenno Silveira ${ }^{5}$. E só

\footnotetext{
${ }^{5}$ Ao fazer referência, num mesmo parágrafo e de forma bem rápida, a Mounin, Steiner, Rónai e Silveira, desejo apenas fazer entrever, de passagem e superficialmente, o estado ainda inicial e tímido dos estudos de tradução em determinado momento do século XX. Não é meu intuito, de forma alguma, como poderia parecer, trazer à luz tais obras como se elas tivessem de ser encaradas da mesma forma. Mounin e Steiner escrevem trabalhos teóricos e de maior fôlego (principalmente o segundo), eminentemente linguísticos (principalmente o primeiro) e tradutológicos, não obstante toquem, de forma leve, em aspectos de etnologia e antropologia. Já Rónai e Silveira são responsáveis por manuais e relatos de experiência, publicações mais modestas e sem quaisquer ambições teóricas, embora agradáveis e úteis.
} 
mais tarde os escritores pertencentes ao grupo concretista iniciariam seu trabalho revolucionário na área. E, se a literatura reivindicou sua autonomia ao menos desde o Romantismo, a tradução ainda não conquistou por completo esse status, pois foi durante muito tempo (e para muitos ainda funciona assim) considerada subliteratura (século XVI), subcrítica (século XIX) e uma linguística ou poética aplicadas (século XX) (BERMAN, 2007, p. 18).

Enfim, a chamada Teoria da Tradução ainda engatinhava enquanto, por outro lado, importa lembrar, a Teoria da Recepção, que dava sustento sólido a uma nova forma de encarar texto, autor e leitor, já estava mais desenvolvida e tornava qualquer posição de rearranjo da escrita e do leitor bastante cômoda, possível e real. Um contexto como esse não permitiu a Barthes sequer a lembrança do tradutor, quando tratou o texto como um espaço de dimensões múltiplas que só o leitor harmoniza: "a unidade de um texto não está na sua origem, mas no seu destino” (BARTHES, 1987, p. 53). Assim, não atentou para o fato de que, como aponta J. Salas Subirat, argentino tradutor do Ulisses para o espanhol, "traduzir é a maneira mais atenta de ler" (apud CAMPOS, 1992, p. 43). O tradutor é leitor e autor ${ }^{6}$ ao mesmo tempo; então (e isso seria um problema para Barthes), aqui temos o caso extremo de um leitor que não só reúne as escritas do texto, mas que também as dispersa na medida em que as tece. Ademais, ainda outros três pontos devem ser colocados: (1) o autor, na verdade, não morreu, sempre esteve entre nós. Houve apenas tentativa de homicídio. O tiro de Barthes não foi fatal, só desacordou a vítima, que ainda respirava. Foucault ficou responsável pela ocultação do corpo, mas, por algum motivo, enterrou o cadáver errado. Agamben, através das pistas deixadas por Foucault, encontrou a cova rasa, exumou o corpo e viu que a vítima foi outra. Quem? Um indigente. De qualquer forma, não importa agora. (2) Seja lá como for, a tentativa de assassinato e a afirmação de desaparição do autor, da forma como foram tramadas, não eram legítimas, em certa medida. (3) A não morte do autor foi também um dos fatores que impediram a entrada em cena do tradutor.

Comecemos pela segunda das três afirmações, pois as outras duas serão tratadas em conjunção. É claro que os textos de Barthes e de Foucault são relevantes e que suas tomadas de posição foram mais que necessárias naquele momento. O primeiro estava coberto de razão quando afirmou que era urgente dar um basta no império do autor (fortaleza que ele ajudou a abalar), assim como o segundo se encontrava mais do que lúcido quando tomou o discurso em lugar do autor e abriu o pensamento para a dimensão da função-autor. Apenas acho um tanto radical dizer que o autor só fecha a escrita, a delimita - o contrário também ocorre. Muitos críticos podem ter sido reducionistas (e o foram), o que justifica a argumentação desses grandes pensadores, mas isso é apenas parte da verdade. Ir até o autor não significa apenas congelar a escrita, pode-se também derretê-la e evaporá-la em direção ao leitor. Compreende-se que naquele momento talvez fosse impossível assumir outra posição, senão aquela que foi tomada, mas isso não nos impede de ver de outra forma.

Leonor Arfuch, no ensaio "O espaço biográfico na (re)configuração da subjetividade contemporânea”, afirma, entre tantas outras coisas, que a biografia de uma pessoa não pertence totalmente a ela, está também em poder dos outros. O simples fato de estarmos vivos e em sociedade já nos coloca para além de nós mesmos. As cartas que escrevemos, os poemas e canções que compomos, os filmes a que assistimos, o time para o qual torcemos, os amores que vivemos, as entrevistas de emprego pelas quais pas-

\footnotetext{
${ }^{6}$ Considerando o tradutor como coautor das obras que traduz, visto que recebe direitos autorais pelo seu trabalho.
} 
samos, a simples e despretensiosa conversa no bar ou a cantada dada/recebida, enfim, tudo que nos toca (em sentido lato) nos revela, nos denuncia e nos faz "reféns". Não importa que queiramos tomar aquela outra via, talvez nunca consigamos ir por ela, já que não só nós estamos no volante - é o que Leonor chama de espaço biográfico (termo tomado emprestado a Philippe Lejeune) e define assim:

um espaço biográfico - espaço/temporalidade - mais dilatado que o gênero [biográfico], pensado não a partir da pureza étnica, mas sim das interações, das inter-relações, do hibridismo das formas, de seus deslizamentos metonímicos, de sua intertextualidade, em resumo, das diferentes maneiras em que as vidas 'reais' - experiências, momentos, iluminações, lembranças - narram-se, circulam e são apropriadas nas incontáveis esferas da comunicação midiatizada (ARFUCH, 2009, p. 114, grifo da autora).

Essa citação, no texto de Leonor, surge no momento em que se pensa o espaço biográfico no contexto do gênero biografia e de outros gêneros, sejam tradicionais, sejam midiáticos modernos. A intenção, que não invalida o argumento presente aqui (pelo contrário), é, a partir da constatação vulgar de que a biografia há muito perdeu qualquer caráter de pureza, entender e estabelecer, de forma maleável, o espaço da infinita interrelação/hibridização dos gêneros, dos discursos, da vida em geral. Mais à frente, a autora é ainda mais clara e explícita no que toca à vida real:

essencial para a vida, a conversação põe por sua vez de manifesto algo inquietante: que nossa biografia não nos pertence por inteiro, que outros - muitos outros - guardam rastros que compartilhamos ou que nos são invisíveis, facetas de nós mesmos que nos escapam, palavras que já esquecemos, gestos, emoções... Outra maneira de dizer que o mito do eu só é possível frente a um você, e então não como essência, mas sim como relação e que esse você mostra - para além do próprio inconsciente - a real impossibilidade da presença: aquilo que somos e que nos escapa, que só existe na experiência dos outros (ARFUCH, 2009, p. 120 , grifos da autora).

Trazendo isso para o ponto da morte/desaparição do autor, percebe-se de modo firme que o autor pode em muito alargar a escrita, as interpretações, os sentidos, o mundo em si. Recorrer à sua figura é também recorrer a múltiplas interpretações e visões sobre alguém - e me refiro ao indivíduo de carne e osso, à sua pessoa, à sua história, aos seus gostos, às suas paixões (BARTHES, 1987, p. 50). Ir até o autor é, concomitantemente, ir até aqueles outros -muitos outros - que estão no "raio de contato e ação" do autor. Daí, o uno faz-se vários, multiplica-se o indivíduo - inclusive o de carne e osso. Ao invés de um mecanismo de segurança, de um significado último; ao invés de um entrave à livre manipulação da ficção, estaríamos, é possível, em campo aberto, mais aberto a possibilidades do que nunca, em que contradições, mentiras e verdades serão intensamente manipuladoras/manipuláveis.

Pode-se dizer que pensar assim é voltar a uma situação pré-Barthes, em que o autor engolia o texto; é querer ordenar a escrita a partir da vida, ela mesma precária de ordem e de coerência. Isto é, os textos de um modo geral estariam voltando a servir de reduto do autor tal qual uma biografia seria o habitat de uma vida; uma biografia, que é a tentativa de ordenar o caos de uma existência, a tentativa de colocar um imenso universo na cabeça de um alfinete. Mas observações como essas não se sustentam. Primeiro, porque a biografia é uma ilusão de ordem (ilusão no sentido de uma ordem definiti- 
va). Para provar isso, basta compararmos entre si várias biografias de um mesmo indivíduo: a ordem e a coesão de um texto biográfico só vão até onde começa o outro, o que prova a refração a que uma vida pode dar origem. Sem contar o conhecimento que temos/formamos, por outros meios, da história de alguém e que nos permite aceitar, refutar, reelaborar o que lemos, ouvimos, vemos, etc. Segundo, assim como podemos partir de uma existência para escrever uma biografia, podemos partir de uma biografia para escrever/des-crever uma vida - é via de mão dupla. Embora a biografia seja o exemplo clássico a ser seguido nesses casos, isso vale para qualquer texto em menor ou maior escala, pois "escrever é colocar a vida em risco" (SALOMÃO, 2006, p. 83). Por isso que escrevi mais acima que a tentativa de assassinato e a afirmação de desaparecimento do autor, como foram premeditadas, não eram legítimas, em certa medida - tirar o autor de cena é limitar a escrita, é fechá-la, apesar de o fantasma reducionista continuar a nos assombrar. De tudo pode-se fazer um uso e a escrita depende do uso que fazemos dela.

Os elementos um e três da enumeração se ocupam da não morte do autor e de como essa não morte também impediu que o tradutor entrasse em cena. Que o autor não morreu é fato óbvio. Apesar de ele ter sido abalado - o que é salutar -, ele nunca deixou de estar conosco, pela simples razão de que seria impossível não estar. Agamben nos faz ver que importa quem fala, pois se alguém, ainda que anônimo, sem rosto e preso à trama da escrita, diz algo, ele prova sua irredutível necessidade. Desse modo, falar (como vem sendo propalado hoje nos estudos literários), stricto sensu, numa volta do autor, não faz qualquer sentido, a não ser que estejamos nos referindo à volta dos que não foram.

E é justamente pelo fato de o autor nunca ter ido que foi possível a Lawrence Venuti tê-lo visto à paisana por aí. Porém, apesar de não mais circular a caráter, o autor é muito influente e, embora tenha cedido algum espaço a outros agentes da escrita, continua enorme e gozando de considerável prestígio, o que impede a ascensão mais sólida do tradutor. Venuti, estudioso e defensor da tradução, de pronto decidiu fazer conhecida sua descoberta e denunciou o tradutor não nas redes sociais, ou no WikiLeaks, ou nos grandes jornais, ou no YouTube - resolveu ser ele mesmo autor, escreveu um livro, em que consta o seguinte:

talvez o fato mais importante na atual marginalidade da tradução seja sua afronta contra o conceito predominante de autoria. Enquanto a autoria é comumente definida como originalidade, auto-expressão num texto único, a tradução é derivada, nem auto-expressão nem única: ela imita outro texto. Dado o conceito dominante de autoria, a tradução provoca o medo da inautenticidade, da distorção, da contaminação. Contudo na medida em que o tradutor deve focalizar-se nas comunidades culturais e lingüísticas do texto estrangeiro, a tradução pode também provocar o medo de que o autor estrangeiro não seja original, mas derivado, fundamentalmente dependente de materiais pré-existentes [...]. Na prática, o fato da tradução é apagado pela supressão das diferenças culturais e lingüísticas do texto estrangeiro, assimilando-as a valores dominantes na cultura da língua-alvo, tornando-a reconhecível e, portanto, aparentemente não traduzida. Com essa domesticação o texto traduzido passa como se fosse o original, uma expressão da intenção do autor estrangeiro. 
A tradução é também uma afronta contra um conceito ainda predominante de erudição [scholarship] que se baseia na pressuposição da autoria original. Visto que essa erudição busca averiguar a intenção autoral que constitui a originalidade, a tradução não somente se desvia dessa intenção, como toma o lugar de outras: ela tem por objetivo direcionar-se a um público diferente ao atender às exigências de uma cultura e línguas diferentes. Em vez de permitir uma compreensão verdadeira e desinteressada do texto estrangeiro, a tradução provoca o medo do erro, do amadorismo, do oportunismo - uma exploração abusiva da originalidade. E, na medida em que o tradutor focaliza as comunidades lingüísticas e culturais do texto estrangeiro, a tradução provoca o medo de que a intenção autoral possa não controlar seu significado e seu funcionamento sociais. Sob o peso desses medos, a tradução tem sido há tempos negligenciada nos estudos da literatura, mesmo em nossa situação atual, onde o influxo do pensamento pósestruturalista questiona de forma decisiva a teoria e a crítica literária de orientação autoral. Quer sejam humanistas ou pós-estruturalistas, os estudiosos contemporâneos tendem a supor que a tradução não oferece uma compreensão verdadeira do texto estrangeiro nem uma contribuição válida ao conhecimento da literatura, doméstica ou estrangeira (VENUTI, 2002, p. 65-66).

Poderia ter feito pequenas citações do fragmento, intercalando-as com paráfrases de minha lavra, mas preferi o longo trecho porque permite ao autor expor suas intenções sem que uma tradução as desvie, as camufle ou as transforme por inteiro... A passagem de Venuti é convincente o bastante para exigir arremedo de qualquer espécie - prescinde de acréscimos.

O protagonista de O homem que não estava lá (2001), Ed Crane (interpretado por Billy Bob Thornton em atuação soberba), lembra um tradutor: é um insignificante e calado barbeiro de uma pequena cidade dos Estados Unidos; leva uma vida extremamente pálida; é casado com uma mulher infiel (papel de Frances McDormand), que simpatizou com ele porque ele não dizia nada, não revelava qualquer originalidade; e quando tentou dar um voo mais alto, de modo a dar uma guinada em sua existência, destruiu a sua vida e a de todos aqueles que lhe eram mais próximos. Ed Crane, num dos poucos momentos em que fala com maior personalidade no filme, quando confessa o terrível crime que cometeu, não lhe dão ouvidos - não havia provas materiais que o colocassem lá, na cena do crime. Não se mostrava realista a possibilidade de ele surgir como assassino. Sua mulher, por outro lado, tudo a colocava lá - ela fraudou a contabilidade da empresa, abriu a porta da loja, na noite do crime, oportunidade em que estava ébria, com a chave que possuía e matou seu patrão e amante (personagem de James Gandolfini) com um objeto de uso feminino. É levada presa e se mata no dia marcado para seu julgamento.

Mais tarde, o bicha $^{7}$ Creighton Tolliver (Jon Polito) é encontrado morto. O crime não foi cometido pelo barbeiro, mas fora fruto de suas ações. Desse assassínio, logo ele é acusado, julgado, condenado e morto na cadeira elétrica. Agora ele virara um monstro manipulador (e traidor (traduttore, traditore) aos olhos de seu cunhado, Frank Raffo (Michael Badalucco)) - fez Dóris (sua esposa) roubar o dinheiro do patrão, o bicha tinha descoberto e Crane viu-se obrigado a matá-lo para encobrir as pistas. Ao crime perfeito que cometeu, ele não foi ligado, mas ao outro, do qual era inocente. É como naqueles casos em que, analisando uma obra traduzida, atribuímos todos os problemas ao tradutor, até aqueles que são responsabilidade do autor, e, ao mesmo tempo, lhe ne-

\footnotetext{
${ }^{7}$ Faço uso da expressão "o bicha” porque assim é feita referência ao personagem de Jon Polito durante o filme.
} 
gamos qualquer participação nas qualidades da obra - o ato extremo e perfeito que cometeu não diz respeito, de forma alguma, ao translado, mas a ação torpe lhe é íntima.

No filme, o fato que mais incomoda o barbeiro é tentar entender por que o cabelo cresce. Em dado momento, inclusive, intrigado e um tanto iluminado, como se carregasse consigo algo único, lembra que certa vez um coveiro lhe disse que o cabelo continua a crescer por um tempo mesmo após a morte, e depois para. Crescem, segundo Crane, como plantas, e ele se pergunta algo do tipo: "o que sai da terra? Seria a alma?" E completa mais ou menos assim: "em que momento o cabelo percebe que ela se foi?" E o tradutor ecoa: "em que momento terei alma?”

Quiçá por isso, na última cena do filme, Crane se mostre tão tranquilo e equilibrado preso à cadeira elétrica. Suas palavras finais são belas e lúcidas, pois talvez com a execução ele poderá exorcizar seus fantasmas. Traduzem também a situação do tradutor que ainda está do lado de cá da autoria, da originalidade e do reconhecimento. O tradutor é o homem que não estava/está lá. O tradutor, assim como o barbeiro, não sabe exatamente o que encontrará do outro lado, mas não o teme e até o deseja. Para isso, ele se prepara há séculos:

não sei para onde estão me levando. Não sei o que encontrarei além da terra e do céu. Mas não tenho medo de ir. Talvez as coisas que não entendo se tornarão mais claras lá. Como depois que uma neblina passa. Talvez a Dóris esteja lá. E talvez lá eu possa dizer para ela todas as coisas para as quais não existam palavras aqui (O HOMEM QUE NÃO ESTAVA LÁ, 2001, cena 13).

João Paulo Matedi Alves jpmatedi@yahoo.com.br Doutorando, Universidade Federal do Espírito Santo 


\section{Referências bibliográficas}

AgAmBen, Giorgio. "O autor como gesto". In: . Profanações. Trad. de Selvino J. Assman. São Paulo: Boitempo, 2007. p. 55-64.

ARFUCH, Leonor. "O espaço biográfico na (re)configuração da subjetividade contemporânea”. In: GALLE, Helmut et al. (Orgs.). Em primeira pessoa: abordagens de uma teoria da autobiografia. São Paulo: Annablume, 2009. p. 113-121.

BANDEIRA, Manuel. A estrela da vida inteira. 20. ed. Rio de Janeiro: Nova Fronteira, 1993.

BARTHES, Roland. “A morte do autor”. In: O rumor da língua. Trad. de António Gonçalves. Lisboa: Edições 70, 1987. p. 49-53.

BenJAmin, Walter. “A tarefa - renúncia do tradutor”. Trad. de Susana Kampff Lages. In: HeIDERMANN, Werner (Org.). Clássicos da teoria da tradução. Florianópolis: UFSC/Núcleo de tradução, 2001. v. 1, p. 188-215. Antologia bilíngue alemão-português.

BERMAn, Antoine. A prova do estrangeiro: cultura e tradução na Alemanha romântica: Herder, Goethe, Schlegel, Novalis, Humboldt, Schleiermacher, Hölderlin. Trad. de Maria Emília Pereira Chanut. Bauru: EDUSC, 2002.

. A tradução e a letra ou o albergue do longínquo. Trad. de Marie-Hélène C. Torres, Mauri Furlan e Andréia Guerini. Rio de Janeiro: 7Letras, 2007.

CAMPOS, Haroldo de. "Da tradução como criação e como crítica". In: Metalinguagem \& outras metas. 4. ed. rev. e ampl. São Paulo: Perspectiva, 1992. p. 3148.

FoucAult, Michel. “O que é um autor?” In: . Estética, literatura e pintura, música e cinema. Trad. de Inês Autran Dourado Barbosa. Rio de Janeiro: Forense Universitária, 2001. p. 264-298. Coleção Ditos e Escritos.

LAGES, Susana Kampff. Walter Benjamin: tradução e melancolia. São Paulo: EDUSP, 2007.

Mounin, Georges. Os problemas teóricos da tradução. Trad. de Heloysa de Lima Dantas. São Paulo: Cultrix, 1975.

O Homem Que Não Estava LÁ. Direção: Joel Coen. Produção: Ethan Coen. Intérpretes: Billy Bob Thornton; Frances McDormand; Michael Badalucco; Richard Jenkins; Scarlett Johansson; Jon Polito; Tony Shalhoub; James Gandolfini e outros. Roteiro: Joel Coen e Ethan Coen. Música: Carter Burwell. Los Angeles: Miramax, 2001. 1 DVD (115 min), widescreen, color.

Pinilla, José Antonio Sabio; SÁNCHEz, María Manuela Fernández. O discurso sobre a tradução em Portugal: o proveito, o ensino e a crítica. Antologia (c. 1429-1818). Lisboa: Colibri, 1998.

RANCIÈRE, Jacques. “Os enunciados do fim e do nada”. In: . Políticas da escrita. Tradução de Raquel Ramalhete, Laís Eleonora Vilanova, Lígia Vassalo e Eloísa de Araújo Ribeiro. Rio de Janeiro: Editora 34, 1995. p. 227-252.

SALOMÃo, Douglas. Zero. Vitória: Secult, 2006.

VALÉRY, Paul. "Variações sobre as bucólicas de Virgílio”. Trad. de Paulo Schiller. In: FAVERI, Claudia Borges; TORREs, Marie-Hélène Catherine (Org.). Clássicos da teoria da tradução. Florianópolis: UFSC / Núcleo de tradução, 2004. v. 2, p. 189-217. Antologia bilíngue francês-português.

VenUTI, Lawrence. Escândalos da tradução: por uma poética da diferença. Trad. de Laureano Pelegrin, Lucinéia Marcelino Villela, Marileide Dias Esqueda e Valéria Biondo. Bauru: EDUSC, 2002. 